嗅裂閉鎖術により治癒した特発性髄液鼻漏の 1 例

\author{
久松 建一・岸保 鉄也・後藤 領・中澤 真理 \\ 上條 篤・水越 昭仁・村上 嘉彦
}

\title{
A Case of Spontaneous Cerebrospinal Fluid Rhinorrhea Cured by Obliteration of the Olfactory Cleft
}

\author{
Ken-ichi Hisamatsu, Tetsuya Ganbo, Rei Goto, Mari Nakazawa, \\ Atsushi Kamijo, Akihito Mizukoshi and Yoshihiko Murakami \\ (Yamanashi Medical University)
}

\begin{abstract}
Non-traumatic cerebrospinal fluid rhinorrhea (CSFR) has a low incidence. However, it should be considered differential diagnosis of running nose because of the risk of recurrent meningitis.

In the cases of CSFR with intact olfaction, this site should be conserved during surgery if possible to preserve the patient's quality of life. However, there have been few reports of surgery to cure CSFR via the cribriform plate fistulae. We experienced a patient with unilateral spontaneous CSFR via the cribriform plate, which was successfully cured by a newly developed simple transseptal procedure conserving postoperative olfaction.
\end{abstract}

Key words : spontaneous CSFR, olfaction, transseptal operation

はじめに

䯣液鼻漏は耳鼻咽喉科クリニックで鼻汁を訴える患者 のなかに時々見いだすことのある疾患である，䯣夜鼻漏 は外傷性と非外傷性とに分類することができる．髄液鼻 漏の殆どは外傷性であり非外傷性のものは少ない。しか しながら反復性の化膿性髄膜炎を起こすことがあるので, 水様鼻漏をきたす疾患の鑑別診断上，非外傷性の髄液鼻 漏を忘れてはならない, 非外傷性の髄液鼻漏のらち, 腫 瘍のような頭蓋内占拠病変や水頭症のような䯣夜漏を引 き起こす原因となる疾患が見られない特発性の髄液鼻漏 は, 非常に稀である. 頭蓋底のらち構造上最も脆弱な部 位は篩板であり, その部位では嗅神経緎維が頭蓋内より 貫いて嗅裂に分布し，嗅覚機能に重要な役割を果たして いる. 嗅覚障害のない䯣液鼻漏の症例では，もし可能で あれば患者の quality of life のために手術によって嗅覚 を犠牲にすべきではない。しかしながら, 䯣液鼻漏で術 後性嗅覚障害を考慮した報告はほとんどない，われわれ
は篩板経由の一側性特発性䯣液鼻漏を経験し, 我々が新 たに開発した経鼻中隔的粘膜骨膜下嗅裂閉鎖術によって 対側の嗅覚を保存しつつ治癒せしめ得た症例を経験した ので報告する．この鼻内手術は鼻中隔矯正術より発展さ せた小手術であり我々耳鼻咽喉科医が容易に施行できる という利点がある。

症例 : 69歳, 女性.

1988年以来, 増強する右側の水様鼻漏に気がついた. 1992年 4 月 4 日山梨医科大学医学部附属病院耳鼻咽喉科 アレルギー外来を受診、それまで某耳鼻咽喉科でアレル ギ一性鼻炎として加療され, 彼女は前屈位で水様鼻漏が 増強すると訴えていた．外傷の既往はなく化膿性䯣膜炎 による二度の入院を経験していた．初診時, 水様鼻漏以 外に, くしゃみ発作, 鼻閉, 頭痛などの自覚症状はなく, アレルゲン皮膚反応，鼻汁中好酸球，八ウスダスト，花 
粉類, 真菌類の抗原に対する $\mathrm{IgE}$ 抗体検査などアレル ギー学的検査は全て陰性であった．前鼻鏡検査扣よびフ ァイバースュピーでは，座位で右側嗅裂付近に水様分泌 物を認める以外に固有鼻腔や鼻咽腔は殆ど正常であった。 右側の上前方に鼻中隔湾曲があるため針状硬性鏡による 嗅裂部粘膜の観察は不可能であった. X線検査, 断層撮 影, CT スキャンでは, 前頭蓋底に骨折線や骨欠損, 特 よび副鼻腔に異常を認めなかった。しかしながら，水様 分泌物中の糖反応陽性であり髄液瘦の存在が疑われた。 定性および定量的な嗅覚機能検査 ${ }^{11}$ により右側の嗅覚異 常が認められた。1992年 9 月21日精査执よび加療の目的 で当科に入院し, 当日, 腰椎穿刺を施行し $1 \mathrm{mCi}$ の indium 111-diethylene triamine pentacetic acid (111 indium-DTPA)を注入， 2 時間， 5 時間， 24 時間後に radio-isotope cisternography が施行された。また 2 時間 後に小綿球を両側嗅裂の上前方, 後下方, 扣上び中鼻道 の下方に扣き，3時間後に取り出し各綿球の放射能を測 定し，バックグラウンドと比較した．その結果右側篩板 および蝶形骨洞，篩骨洞天蓋からの䯣液漏の存在が疑わ れた(表 1 )。

1992年 9 月 28 日，䯣液瘦の局所診断と保存的治療のた めに Gelfoam ${ }^{\circledR}$ がフィブリン糊とともに右側嗅裂に挿入 された。この処置により䯣液鼻漏は改善したが 7 日後に 再発した。

2 時間後の脳槽シンチグラムと綿球の放射能測定の結

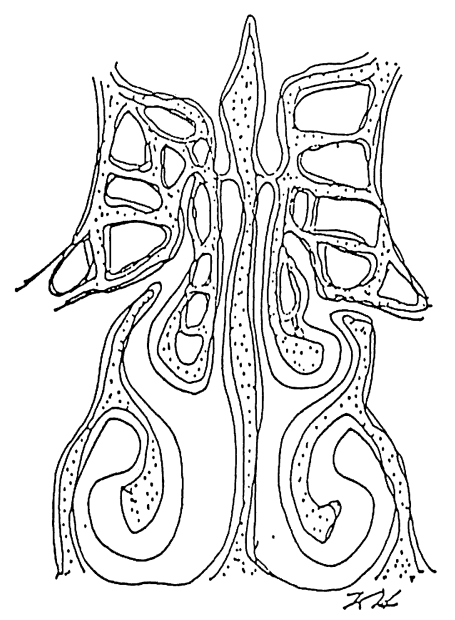

術前
表 1 111Indium-DTPA を䯣液内に注入 2 時間後の鼻腔各部位 に留置した小綿球の放射能評価(ハッックグラウンドとの比)

\begin{tabular}{ccccc}
\hline \hline & $1992.9 / 21$ & $1992.10 / 30$ & $1993.12 / 17$ \\
\hline 右側 : 嗅裂 & 前方 & 754 & 32 & 4 \\
& 後方 & 215 & 35 & 4 \\
中鼻道 & 30 & 35 & 1 \\
左側 : 嗅裂 & 前方 & 5 & 7 & 8 \\
& 後方 & 6 & 5 & 2 \\
中鼻道 & 5 & 6 & 1
\end{tabular}

果は依然䯣液鼻漏の存在を示唆していた。そこで髄液漏 の根治のためにつぎの手術を局麻下に施行した.

手術方法と所見

局所麻酔下に鼻中隔矯正術を施行した後，中鼻甲介の 鼻中隔方向への可動性を容易にするためと篩骨洞天蓋を 観察するために，経鼻的節骨洞根本手術を施行した．そ の結果節骨洞天蓋よりの䯣液漏は発見されなかった．嗅 裂のファイバースコピーにより右嗅裂の天蓋より䯣液の 流出を認めた。しかし蝶形骨洞の自然口に異常は認めな かった．嗅裂に面した中鼻甲介と鼻中隔の粘膜上皮を摇 爬した後，嗅裂の空間を埋めるために採取した鼻中隔軟 骨を $20 \mathrm{~mm} \times 4 \mathrm{~mm}$ 飞調整し，右側鼻中隔粘膜骨膜と篩 骨篩板の間に挿入しフィブリン糊にて固定した（図 $1 \mathrm{a}$, b). その後 $5 \%$ ホスホマイシンを含有する生理食塩水

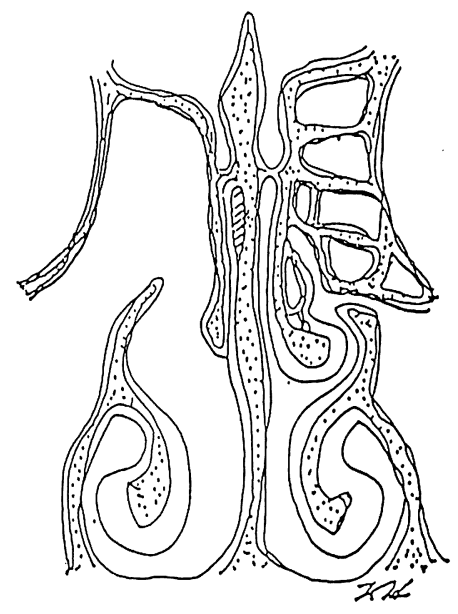

術後

図 $1 \mathrm{a}$ 


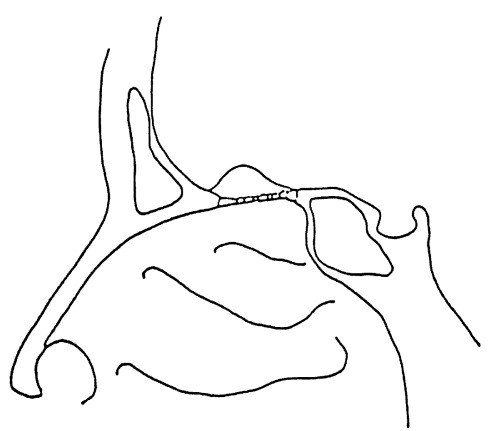

術前

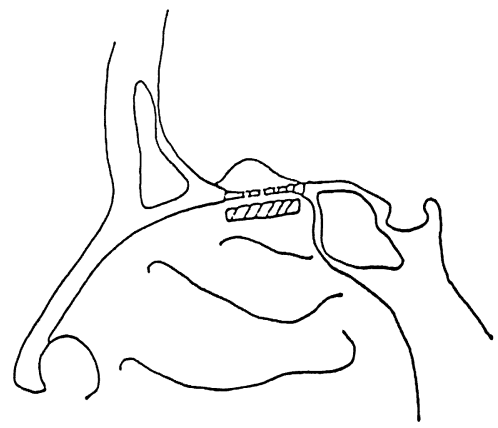

術後

図 $1 \mathrm{~b}$

に浸したSponsel ${ }^{\circledR}$ を篩骨洞に挿入圧迫した。術後 3 日 後にSponsel ${ }^{\circledR}$ を除去した. 術後 7 日後に退院, 以後現 在にいたるまで，髄液鼻漏扣よび髄膜炎は経験されてい ない，脳槽シンチグラフィーおよび小綿球による鼻漏の 放射能測定も陰性であった. 左側の嗅覚は正常であり現 在も経過観察中である.

\section{考察}

䯣液鼻漏は病因から“外傷性” と“非外傷性” に大別 することができる. 前者は頭部外傷, 手術などにより起 こされる髄液鼻漏である。後者はさらに“髄液圧充進型 䯣液鼻漏 high pressure leak” $と$ “正常髄液圧型髄液鼻 漏 normal pressure leak”に分類される.

䯣夜圧え進型は腫瘍, 水頭症などによるものであり, 正常髄液圧型は先天異常, 局所萎縮, あるいは骨髄炎に よる骨欠損が原因とされている2)。非外傷性髄液鼻漏は 稀であるが，正常髄液圧型は髄膜炎を繰り返す危険性が あるとされている。

本症例は, 非外傷性であり, 特発性の正常髄液圧型で あった，その特徵は，Ommaya ${ }^{2)}$ が報告したところによ ると成人に多く(28歳以上)，女性に多い(男女比 約 2 : 1).また，嗅覚機能は通常保たれていることが多いし かし嗅覚検查を施行された報告は殆どない，本症例のよ らと篩板の䯣液瘦の存在する場合は患側の嗅覚障害を起 こすので，一側ずつの嗅覚検査を施行する必要がある.

䯣液鼻漏の局所診断に嗅覚検査が有用であることをここ で強調したい。

䯣液鼻漏の外科的治療としては，頭蓋内アプローチと 頭蓋外アプローチがあるが，後者は鼻外的に行われる事
が多い，経笠骨洞的瘦孔閉鎖術は，1964年，Menig ${ }^{3)}$ に より報告された．前頭洞，篩骨洞経由の鼻外的瘦孔閉 鎖術が1966年, Aboulker ら4)により報告されている. Ommaya ${ }^{2)}$ は脳外科医の立場から, 䯣液鼻漏は, 頭蓋内 アプローチにより䯣膜の欠損部を修復すべきであり，大 部分の外傷性と非外傷性の髄液鼻漏に対し, 硬膜内アプ ローチをすべきであると述べている。また， $\mathrm{McCoy}^{5}$ は脳外科的に治療した活らがよい症例と, 耳鼻咽喉科的 に治療した注らがよい場合があると述べている。事実, Ommaya ${ }^{2)}$ も蝶形骨付近への頭蓋内アプローチは極めて 危険を伴うので, 頭蓋外, 即ち, 経鼻的アプローチを卜 ルコ鞍を経由した蝶形骨洞への骨道液漏の治療に対し推奖 している，篩板や穊骨洞，蝶形骨洞の天蓋からの䯣液漏 の治療のためにさまざまな鼻科学的アプローチが考察さ れてきた5) 10). しかしながら，嗅覚機能の保存につい ての考虑は, 特に頭蓋内手術ではなされていなかった. 少なくとも片側の嗅覚の保存のために, 術前に確実な䯣 液瘦の局所診断を行い, 髄液瘦への最良の手術式術式を 選択寸る必要がある。

䯣液瘦の局所診断は, 脳槽シンチグラフィーや髄夜鼻 漏の経路の可能性のある, 中鼻道, 嗅裂, 下鼻道 (耳管 咽頭孔経由)111などに置いた小綿球の放射能の測定が頭 部X線撮影，CT スキャンとともに必要である。ただし， 綿球の放射能の測定法はアイソトープによる相互污染の ために診断率が低下寸る可能性がある。このことは，本 症例に打いても経験された(表 1)。針状硬性鏡は篩板経 由の髄液鼻漏の直接的な確認に有用である。嗅裂の観察 は嗅覚外来のルーチン検査として針状硬性鏡を用いて施 行されている12). 
経鼻中隔的粘膜骨膜下嗅裂閉鎖術は鼻内手術でしかも 患者の quality of life に必要な嗅覚を対側のみであるが 保存が可能であることが長所ともなっている. 従って, 篩板経由の髄液鼻漏の手術として第一に試みるべき価值 があろら．鼻科学の臨床の見地から著者は次の 2 点を強 調したい。即ち，第一に，耳鼻咽喉科医は髄液鼻漏の局 所診断に関与すべきである。髄液鼻漏の経路に置いた小 綿球の放射能の測定や tau-transferin ${ }^{13)}$ の測定は有用性 が高く，また，嗅裂の内視鏡検査や固有鼻腔や鼻道のフ ァイバースコピーは嗅覚検査と同様に髄液鼻漏の診断に 有用な情報を与えるからである1).

これらの内視鏡検査は最近，ファイバースコープや硬 性鏡の開発，改良に伴い耳鼻咽喉科領域では routin work となってきている．術前の鼻腔の内視鏡検査はX 線検査と同様に必須である，第二に，術者は嗅覚の重要 性を認識すべきであり，患者の quality of life のために 嗅覚を保存すべく術前の局所診断に基づき，適当な術式 を選択すべきである，一度，術中に嗅神経線維が切断さ れれば嗅覚の回復は困難であろら．術者は，少なくとも 一側の嗅覚の保存しながら注意深く髄液鼻漏の手術を行 らべさである。

\section{文献}

1) Takagi SF : Clinical aspects of olfaction. Human Olfaction (by Takagi). pp 84 94, University of Tokyo Press, Tokyo, 1989.

2) Ommaya AK : Spinal fluid fistulae. Clin Neurosurg 23 : 363 392, 1976.

3) Mennig $\mathrm{H}$ : Heilung einer schwieringen Liquorfistel druch rhinochirurgisches Voergehen. Z. Laryngol Rhinol Otol $43:$ 412 9, 1964.

4) Aboulker P, Le Beau, Sterker JM, et al : Traitement des fistules meningees ethmoido-frontales. Apropos de 15 cas operes avec succes par voie exocranienne. Ann Oto- laryngol (PARIS), $83: 27 \sim 32,1966$.

5 ) McCoy G : Cerebrospinal rhinorrhea; a comprehensive review and a definition of the responsibility of the rhinologist in the diagnosis and treatment. Laryngoscope $73:$ 1125 1157, 1963.

6) Montgomery WW : Cerebrospinal rhinorrhea. Otolaryngol Clin North Am $6: 757 \sim 771,1973$.

7 ) McCabe BF : The osteomucoperiosteal flap in repair of cerebrospinal fluid rhinorrhea. Laryngoscope $86: 537 \sim$ 539, 1976.

8 ) Hirsch 0 : Successful closure of cerebrospinal fluid rhinorrhea by endonasal surgery. Arch Otolaryngol $56: 1 \sim 13$, 1952.

9 ) Schreimer L and Herrmann A : Die operative Behandlung der nasalen Liquorrhoe mit der Septum- und Muschelschleimhaut-Plastik. Arch Ohr-, Nas-Kehlk Heilk $188: 418,1967$.

10) Samii $M$ and Draf W : Surgery of traumatic lesions of the anterior skull base. Surgery of the skull base. An interdisciplinary approach. With a chapter on anatomy by J Lang Berlin, (ed by Samii M, Draf W). pp 127 153, Springer-Verlag, Heidelberg, 1989.

11) Charles DA and Snell D : Cerebrospinal fluid rhinorrhoea. Laryngoscope $89: 822 \sim 826,1978$.

12) Shirakura $M$ and Asaka $H$ : Endoscopic observation for the diagnosis of olfactory disturbance. Olfaction and Taste XI . Proceedings of the 11 International Symposium on Olfaction and Taste. (ed by Kurihara K, Suzuki N, Ogawa H). pp 623 625, Springer-Verlag, Tokyo, 1994.

13) Yokoyama $K$, Hasegawa $M$, Sano $K$, et al : Diagnosis of CSF rhinorrhea; detection of tau-transferin in nasal discharge. Otolaryngol Head Neck Surg $98: 328 \sim 332$, 1988.

$$
\left(\begin{array}{l}
\text { 別刷請求先 : 久松 建一 } \\
\text { 于409-38 山梨県中巨摩郡玉穂町下河東 } 1110 \\
\text { 山梨医科大学医学部耳鼻咽喉科学教室 }
\end{array}\right)
$$

